\title{
Rumen-protected methionine in cattle: influences on reproduction, immune response, and productive performance
}

\author{
Metionina protegida da degradação ruminal em bovinos: \\ influências na reprodução, resposta imune e desempenho produtivo
}

\author{
Matheus Gomes Lopes ${ }^{1 *}$ (D), José Henrique Echenique Dominguez ${ }^{1}$ (D), Marcio Nunes Corrêa' (D), \\ Eduardo Schmitt ${ }^{1}$ (D), Geferson Fischer ${ }^{1}$ (D)
}

\begin{abstract}
Nowadays, information and knowledge generated about the main ingredients used in cattle diets have enabled greater assertiveness in their formulation. Among the ingredients, amino acids stand out as a promising tool, capable of reducing total crude protein (CP) levels and adjusting optimal metabolizable protein concentrations in diets. Nutritional programs allow diets due to amino acid requirements, providing the opportunity to increase the efficiency of the use of dietary nitrogen, increasing the scarce protein concentrates, maintaining or even boosting performance. This review aimed to present the influences of methionine, in its formulation protected from ruminal degradation, according to reproductive parameters, immune response, and productive performance in cattle. Reproduction-related benefits are linked to the early days of embryonic implantation in the uterine environment, which initially secretes through the histotroph produced by endometrial glands, the nutrients needed to develop the conceptus until implantation, and vascular communication with the mother. Given the immune response, the main results are related to the benefits of innate immunity, with marked increase in phagocytic capacity of neutrophils and monocytes, as well as an important antioxidant effect mediated by methionine products, such as glutathione. When evaluating the influences on productivity, the most evident correlation is the increase in protein in the milk of cows supplemented with methionine. Over the past decade, studies investigating the potential benefits of this strategic supplementation in beef cattle were intensified, expanding the opportunities for the development of new experimental projects.
\end{abstract}

KEYWORDS: amino acids; antioxidants; histotroph; protein.
RESUMO: Atualmente, as informações e o conhecimento gerado sobre os principais ingredientes utilizados em dietas para bovinos possibilitaram maior assertividade em suas formulaçóes. Dentre esses ingredientes, os aminoácidos se destacam como uma ferramenta promissora, capaz de levar à reduçáo nos níveis totais de proteína bruta e ajustar as concentraçóes ideais de proteína metabolizável nas dietas. Programas nutricionais permitem formular dietas por exigências de aminoácidos, oportunizando o aumento na eficiência de utilizaçáo do nitrogênio dietético, reduzindo dispêndios com concentrados ricos em proteína, com a manutençáo, ou ainda, incremento de desempenho. Esta revisáo buscou apresentar as influências da metionina, em sua formulaçáo protegida da degradação ruminal, frente a parâmetros reprodutivos, resposta imune e desempenho produtivo em bovinos. Os benefícios relacionados à reprodução se mostram ligados aos primeiros dias de implantação embrionária no ambiente uterino, que inicialmente secreta, através do histotrofo produzido por glândulas endometriais, os nutrientes necessários para o desenvolvimento do concepto até a implantação e comunicação vascular com a mãe. Dada a resposta imune, os principais resultados estão relacionados aos benefícios da imunidade inata, com aumento acentuado da capacidade fagocitária de neutrófilos e monócitos, assim como um importante efeito antioxidante mediado por produtos originários da metionina, como a glutationa. Por fim, quando avaliadas as influências em produtividade, a correlaçâo mais evidente é o incremento em proteína no leite de vacas suplementadas com metionina. Na última década, os estudos que investigam os potenciais benefícios dessa suplementação estratégica em bovinos de corte foram intensificados, abrindo um caminho de oportunidades para o desenvolvimento de novos projetos experimentais.

PALAVRAS-CHAVE: aminoácidos; antioxidantes; histotrofo; proteína. 
Since the National Research Council (NRC) update in 2001, and the development of the Cornell Net Carbohydrate and Protein System (CNCPS), the methodologies for formulation and adjustment of diets in cattle farming have been renewed (NRC, 2001). Over the past few decades, steady advances in research in an area now called precision nutrition is enabling the development of more detailed tools and technologies for to distribute and balance nutrients essential for an efficient diet. Among these nutrients, proteins are the most abundant and versatile macromolecules in functionality in living things. This protein versatility is directly related to the number, class, and sequence of amino acids that make up their structural units (GONZÁLEZ; SILVA, 2006).

Amino acids, which are considered the "building blocks" for proteins, act as precursors of several functional biomolecules, and are involved in metabolic processes, such as skeletal and muscular development, productive and reproductive performance, and they also determine important regulatory effects on immune responses (PAUL; DEY, 2015; STOVER et al., 2017). All known proteins in the organism are made up of twenty different types of amino acids, grouped through peptide bonds and called protein amino acids. The body's ability to synthesize these molecules gives it an important, commonly used, classification consisted of essential amino acids, which are not synthesized and need to be incorporated into the diet, and non-essential amino acids, made from available substrates (JACKSON, 1983).

In cattle, ruminal protein components are rapidly degraded by the rumen microbiota into peptides and amino acids, that will be reused for microbial protein synthesis (REIS et al., 2016). Rumen-synthesized microbial protein and rumen non-degradable proteins associated with endogenous proteins contribute to the metabolizable protein (MP) requirements needed for maintenance, growth, reproduction, and production of cattle (ZANG et al., 2017).

Currently, with the development of automated programs that include amino acid requirements through the profile of these nutrients in dairy cows, it is possible to formulate diets seeking greater protein use efficiency, maximizing yield and increasing milk components. On the other hand, only over the last decade, research on the possible increments of this strategic supplementation are being intensified in beef cattle. WATERMAN et al. (2014) conducted a new evaluation of NRC Beef Cattle 1996, addressing the concept of metabolizable protein in a model of female cattle raised in extensive grazing systems. The authors identified model inefficiencies that could be adjusted to improve the accuracy of protein requirement predictions in this category. This underlines the importance of interpreting dietary nitrogen and specific limiting amino acids with the impact of rumen microbiota and microbial protein synthesis. Considering the nutritional requirement for amino acids is a strategy that allows to reduce the diet's levels of crude protein (CP), increasing the effectiveness in the relation between secreted nitrogen and consumed nitrogen, with a consequent decrease in ruminal loss of ammonia, leading to cost reduction in the diet, and lower environmental impacts generated by the herd (SCHWAB, 2010).

Research has shown the essentiality and limitation of certain amino acids, such as methionine in cattle, and strategies to increase the availability of these nutrients by protecting rumen degradation are being used (WATERMAN et al., 2012). Methionine is considered an aliphatic and sulfurized essential amino acid, acting as a precursor to carnitine, creatine, cysteine, homocysteine, and succinyl-CoA. In addition, it acts on lipid metabolism and activation of antioxidant enzymes, such as methionine sulfoxide reductase $\mathrm{A}$, and biosynthesis of glutathione, important molecules against oxidative stress. Current studies show that methionine can regulate metabolic processes, digestive functioning, uterine environment, and the immune system of mammals (MARTÍNEZ et al., 2017).

Methionine-based supplements are available in different formulations, but the use of protection-free amino acids in ruminants becomes expensive and unjustified in the face of interference from ruminal microorganisms. Despite that, methionine forms protected from ruminal degradation, formulated mainly with the use of physical coatings, with $\mathrm{pH}$-sensitive polymers and lipid compounds, or analogous forms linked to hydroxyl or isopropanol groups, were efficient to reduce the need for incrementing $\mathrm{CP}$ in the diet, increasing nitrogen use efficiency in dairy cows (CHEN et al., 2011). Methionine supplementation in a formulation that prevents degradation by the rumen microbiota increases its bioavailability (GRAULET et al., 2005), increasing the entry of this amino acid into the one-carbon metabolic cycle, where it can be converted into S-adenosyl-L-methionine (SAM-e), the most relevant biological molecule in methyl group donation, and essential for the mechanism of DNA methylation and gene expression regulation (MARTINOV et al., 2010). The aim of this review is to address the main studies performed today on cattle supplemented with methionine protected from ruminal degradation, focusing on the influences provided on reproductive parameters, immune response, and productive performance.

\section{METHIONINE AND ITS INFLUENCES ON REPRODUCTION}

The period for ruminants to maternally recognize gestation is a complex and crucial moment for embryonic development, related to endocrine, autocrine, and paracrine mechanisms (ANTONIAZZI et al., 2011; NISWENDER et al., 2000). These early days of conception occur in the oviduct, with the arrival of the embryo to the uterine horn, approximately five 
days after fertilization. Until the seventh day, the embryo assumes the blastocyst stage through a stretching phase until the twentieth day of gestation (BETTERIDGE et al., 1980). In cattle, the period when the conceptus signals its presence to the mother coincides with this embryonic elongation and the time when the maximum production of interferon-tau protein (IFNT) occurs (ROBERTS et al., 2008).

IFNT acts as paracrine signaling in the uterine environment, in conjunction with progesterone, and stimulating the production of histotroph by the endometrium, which enables and increases nutrition for the embryo (RIBEIRO et al., 2016). The histotroph is composed of amino acids, proteins, carbohydrates, lipids, and ions produced by the endometrial glands, and plays an important role in meeting embryo nutrient demand (SPENCER et al., 2004). Until the beginning of implantation, which occurs as from the twentieth day, the embryo remains floating in the intrauterine environment and depends completely on the uterine secretions constituted by the histotroph to reach its development, until the establishment of a vascular relation through maternal caruncles (SPENCER et al., 2003).

Most amino acids physiologically have higher concentrations in the uterus and oviduct than at the plasma level (HUGENTOBLER et al., 2007). During pregnancy, the secretory endometrium has mechanisms that result in significant increases in concentrations in the uterine lumen of amino acids, considered the most limiting in dairy cows, such as methionine, lysine, and histidine (GROEBNER et al., 2011). The same authors argue that this increase in uterine amino acid levels, coinciding with the embryonic elongation period, can be explained by the increase in specific amino acid transporters stimulated by IFN-Tau production, aimed at increasing the supply of these nutrients while the conceptus lengthens. Thus, the understanding of how plasma and uterine amino acid concentrations interfere with the different stages of embryonic growth is being studied by researchers in our research group and at United States universities.

Recently, our group investigated the effects of methionine supplementation protected from rumen degradation in preimplantation embryos period, through a study conducted by ACOSTA et al. (2016) at the Department of Animal Sciences at the University of Illinois. Multiparous Holstein cows were randomly divided into two treatments, between 31 and 72 days postpartum, including a control group without supplementation, and a group supplemented with protected methionine. After standard protocol of superovulation 60 days postpartum, and embryo washing 6.5 days after artificial insemination, the global methylation and lipid content of embryos were evaluated. There were no differences in recovery rates, quality and embryonic cells; however, embryos from methionine-supplemented cows had lower overall methylation levels and higher lipid content. The results lead to the conclusion that methionine supplementation impacts embryo preimplantation, improving survival capacity, seen there is strong evidence that endogenous lipid reserves serve as an energy substrate for the conceptus (MARTINOV et al., 2010). According to STURMEY et al. (2009), lipid reserves serve as a source of energy for pre-implanted embryos and contribute to membrane synthesis. Thus, a higher lipid accumulation in preimplanted embryos increases their survivability.

Embryonic quality was also evaluated by SOUZA et al. (2012), who searched 570 embryos from methionine supplemented cows, and found no differences in fertilization rates and qualitative parameters, confirming that, at least from a morphological point of view, methionine supply did not alter the early development of embryos.

Moreover, also at the University of Illinois, ACOSTA et al. (2017) evaluated the effects of methionine supplementation protected from ruminal degradation on the steroidogenic potential of the first postpartum dominant follicle in multiparous Holstein cows. Supplementation did not influence the days until first ovulation, the number of cows that ovulated in the first follicular wave, and the plasma and follicular concentrations of estradiol and progesterone. However, differences were found with higher concentrations of methionine in the follicular fluid of the first postpartum follicle, and changes in mRNA expression in follicular cells of methioninesupplemented cows.

The same set of animals was used to determine the effects of methionine supplementation on vaginal discharge and uterine cytology. Endometrial samples were collected using cytological brushes and were fixed on slides for polymorphonuclear cell (PMN) counting. After evaluating PMN concentrations, no differences were observed between treatments (SKENANDORE et al., 2017).

In vitro studies evaluated whether methionine metabolism was necessary for the development of bovine embryos. Ethionine or methionine solutions were added to the embryo cultures, with the hypothesis that ethionine would block methionine metabolism in the one-carbon pathway. Results point out that ethionine did not inhibit embryo development until the morula stage but made it impossible to reach the blastocyst stage. In contrast, developing to the blastocyst stage was partially restored by the addition of SAM (IKEDA et al., 2012). Methylation occurs by the covalent addition of a methyl group $(\mathrm{CH} 3)$ at position 5 of a cytosine pyrimidine ring to 5 -methylcytosine $(5 \mathrm{mC})$; at $5 \mathrm{mC}$ it is considered to be the "fifth nucleotide". DNA is methylated through the action of DNA methyltransferases (DNMTs) and the universal donor of the methyl group is SAM, the main enzyme responsible for this supply of $\mathrm{CH} 3$ group when associated with DNA (NICIURA; SARAIVA, 2014). DNA methylation through DNMTs is an essential pathway for epigenetic regulation of gene expression. Therefore, the pre-implantation development of embryos in mammals is a critical period for establishing the epigenome, being susceptible to epigenetic effects, proving 
that disruption in homeostasis in methionine metabolism can promote epigenetic disorders with consequences in embryonic development (JAENISCH; BIRD, 2003; STEELE et al., 2005; WRENZYCKI et al., 2005). Thereby, methionine shows a fundamental function in embryo advancement in cattle from the early stages from morula to blastocyst.

In addition, authors such as PENAAGARICANO et al. (2013) investigated the genomic influences of methionine supplementation with the recovery of high-quality embryos from cows supplemented, or not, with protected methionine, proving the ability of modulation in the expression of genes related to embryonic development. A total of 276 genes were expressed with significant difference in supplemented cow embryos, with marked silencing in the vast majority of genes, explained by the author as an expected response, given the direct correlation between increased methionine concentrations and increased methylation of the DNA.

Few recent studies discuss the effects of protected methionine supplementation on the reproductive performance in beef cattle. Our research group designed an experiment to determine the impacts of a protected methionine-enriched mineral supplement on follicular dynamics and reproductive rates in 100 Nulliparous Brangus beef heifers (5/8 Angus $\times 3 / 8$ Brahman) submitted to TAI protocol. After 45 days of supplementation, the animals were synchronized in a standard TAI protocol and the dominant follicle diameters were evaluated between the eighth and tenth day of protocol, with 24-hour intervals. The group of heifers receiving methionine tended to have a greater follicular diameter in millimeters compared to the control group $(11.76 \pm 2.07$ vs. $10.86 \pm 2.75)$. However, there was no difference in the conception rate at 30 and 60 days after the TAI (DOMINGUEZ et al., 2017).

Other authors also demonstrated effects of protected methionine on cross-bred heifers (Bos taurus $x$ Bos indicus) supplemented for 45 days with a mixture of molasses and urea enriched with methionine. Serial ovarian ultrasound measurements were performed to determine follicular growth dynamics, finding a higher percentage of ovarian follicles with a diameter greater than $9 \mathrm{~mm}$ in the treatment group (26.7\%), compared to the control group (6.4\%) during the supplementation period. When the supplementation period was over, the percentage of females with follicles larger than $9 \mathrm{~mm}$ was $60 \%$ in heifers supplemented with methionine, and $18.8 \%$ in heifers not receiving supplementation. In addition, the percentage of ovulation after estrus synchronization period ranged from $86.7 \%$ in the supplemented group to $62.5 \%$ in the control group, proving that the added methionine supplement favored the establishment of ovarian activity and follicular dynamics (ALONSO et al., 2008).

In conclusion, the benefits of protected methionine supplementation in reproductive parameters, especially related to the embryonic pre-implantation period can be highlighted when the absence of vascular communication with the mother makes the concept totally dependent on intrauterine fluids for development. Besides that, when observing the results of increased ovarian activity, both follicular growth and dominant follicle size, the strategy of supplementing certain categories becomes viable.

Therefore, a promising path in research related to reproductive performance has been pointed out. Following studies directed to the dairy sector, our research group is currently developing projects aimed at clarifying the effectiveness of methionine in beef cattle, including the evaluation of different animal categories and their potential benefits.

\section{METHIONINE AND ITS INFLUENCES ON IMMUNE RESPONSE}

A deficiency of proteins or amino acids in the diet compromises the proper functioning of the immune system and increases the susceptibility of infectious diseases in animals and humans (CALDER; YAQOOB, 2003). In recent years, cellular and molecular mechanisms involving these processes began to be clarified, and indicate an important role for amino acids in the immune response, regulating leukocyte activation, antioxidant molecules, gene expression, and cytokine and antibody production (LI et al., 2007).

Dietary specific amino acid supplementation is responsible for reducing morbidity and mortality in infectious conditions. The development of nutritional immunology emerged from cases of malnutrition and infection, which are the factors that most compromise the vital system of both humans and animals. Such concept of nutritional immunology brings together methodologies of nutritional and immunological research to clarify the function of nutrients in the body (CALDER; YAQOOB, 2003).

The immune system is conceptually divided into physical defenses, exemplified by natural barriers, such as skin, innate immunity composed of complement system, granulocytes, macrophages, dendritic cells and natural killers, and specific immunity composed of $\mathrm{T}$ and $\mathrm{B}$ lymphocytes, as well as immunoglobulins (TIZARD, 2014). Both innate and specific systems are subject to a certain amount of amino acids for protein and polypeptide synthesis. In this sense, studies were conducted to search for amino acids, capable of assisting the immune system, because they have important functions in leukocyte activation and proliferation, oxidative stress reduction, gene expression, and production of cytokines and immunoglobulins (LI et al., 2007).

The evaluation of the innate immunity benefits provided by two different sources of protected methionine was performed in 56 multiparous Holstein dairy cows supplemented during the transition period. By isolating PMN leukocytes from the 
blood, the authors determined phagocytic capacity after a challenge with Escherichia coli and demonstrated increased phagocytic power of neutrophils at 21 days postpartum in supplemented cows (OSORIO et al., 2013). The same group of researchers evaluated blood and liver biomarkers linked to liver function, inflammation and oxidative stress in $37 \mathrm{mul}-$ tiparous Holstein cows supplemented with two sources of protected methionine in the transition period. The results indicated a decrease in positive acute phase proteins, such as ceruloplasmin and serum amyloid $\mathrm{A}$, increase in proinflammatory cytokines, such as interleukin-6 (IL-6), increased capacity of free radicals plasma absorption, and increase in products derived from methionine, such as hepatic glutathione and carnitine, contributing to a potent antioxidant effect in animals belonging to the methionine supplemented groups (OSORIO et al., 2014).

Similar results were recently found by BATISTEL et al. (2018) by supplementing 60 multiparous Holstein cows with methionine protected through ethyl cellulose nuclei, during the peripartum period. an increase in liver functionality were observed at higher concentrations in the supplemented group in plasma cholesterol, albumin, paraoxanase, and IL-6 levels. In addition to the reduction in positive acute phase proteins, such as haptoglobin, a higher phagocytic capacity of neutrophils and oxidative burst was observed, compared to the control group. The anti-oxidation potential was demonstrated by the ferric reduction power and correlated to the circulating increases in the levels of $\beta$-carotene, tocopherol, total, and reduced glutathione.

Improvement in immunometabolic status of methionine-supplemented dairy cows protected from ruminal degradation was observed by ZHOU et al. (2016a), in a study of 48 multiparous Holstein cows. Neutrophil and monocyte phagocytic capacity analyzes were performed, jointly with the oxidative burst measurement provided in phagocytosis situations. Increased phagocytic potential and oxidative burst were observed in cows supplemented with methionine. This same group had higher concentrations of plasma cholesterol and paraoxanase, indicating better liver function. There was also an increase in albumin and IL-6, associated to a decrease in haptoglobin and interleukin-1 $\beta$ (IL-1 $\beta)$, a situation that would lead to a lower proinflammatory state.

In a recent study, 33 multiparous Holstein cows were used to determine the effects on whole blood immune response of animals supplemented with methionine protected from ruminal degradation. An ex vivo lipopolysaccharide (LPS) challenge was performed from whole blood samples to determine IL- 6 and IL-1 $\beta$ levels, and to measure phagocytosis capacity in neutrophils and monocytes. Corroborating another study (ZHOU et al., 2016a), supplemented cows had higher postpartum phagocytic effectiveness and increased concentrations of pre-partum IL- 6 and IL- $1 \beta$ (VAILATI-RIBONI et al., 2017). In contrast, $P M N$ leukocyte isolation in neonatal calves was performed by ABDELMEGEID et al. (2017) to evaluate the effect of methionine supplementation on methionine cycle-related gene expression and innate immune response. The results showed that methionine supplementation caused a reduction in interleukin-10 (IL-10), IL-6 gene expression in Toll-Like pattern recognition receptors (TLR-4), and transcriptional pathways $(\mathrm{NF \kappa} \beta)$, indicating that the treatment attenuated the inflammatory activation of PMN cells.

In our research group, JACOMETO et al. (2016), together with the Mammalian NutriPhysioGenomics research laboratory at the University of Illinois, performed a study on the effects of maternal methionine supplementation protected from ruminal degradation on blood and liver biomarkers, related to energy metabolism, inflammation, and oxidative stress in Holstein neonatal calves. In all of them, 23 blood biomarkers and 24 genes were evaluated by liver transcriptome. The animals from mothers supplemented with methionine during the pre-delivery period had lower concentrations of reactive oxygen species (ROS) and ceruloplasmin, indicating higher antioxidant capacity and stress reduction.

Thus, the synthesis of the results obtained in the last decades of research on the immunonutriconal power of methionine, in its protected form from ruminal degradation in cattle, leads to the conclusion that a large part of the benefits come from the effect on liver function protection and increase. The marked increase in concentrations of key components in the removal of free radicals with potent antioxidant effects, such as glutathione, show the ability of this strategy to reduce oxidative stress.

Moreover, innate immunity is the target of recent studies, with a marked increase in neutrophil phagocytic capacity, associated with an increase in ROS, thus proving a favored anabolic activity of leukocytes. Yet, when associated to regulatory effects in relation to inflammatory processes, this dietary strategy is perceived as a tool for immunomodulation, with some contradiction in certain studies that observe an increase in proinflammatory components against other results that indicate marked reduction in inflammation, proven with the measurement of acute phase proteins and important interleukins in these processes.

\section{METHIONINE AND ITS INFLUENCES ON PRODUCTIVE PERFORMANCE}

When researching the influences of protected methionine supplementation on cattle performance, we observed that the studies are directed to the dairy sector, showing a lack of results in beef cattle. Our research group is recently developing studies that seek to clarify the possible benefits of this amino acid in beef cattle, pointing promising results 
in certain categories. We evaluated the effects of protected methionine supplementation on weight gain in beef heifers submitted to a fixed-time artificial insemination (TAI) protocol. The experiment was conducted in an experimental farm located in the Midwest region of Rio Grande do Sul State, Brazil, using 100 Brangus (5/8 Angus vs. 3/8 Brahman) heifers, aged from 18 to 24 months. The animals were divided into two homogeneous groups, where the control group was kept in native pasture with access to mineral supplementation and the methionine group, kept under the same conditions, with methionine added to the mineral supplement. Supplementation for both groups began 45 days before the TAI protocol, and consumption was monitored every 15 days until the end of the experimental period. The methionine group obtained a higher weight, compared to the control group $(398.57 \pm 28.47$ vs. $389.27 \pm 21.44$. In the weighing performed at irregular intervals, an interaction between time and treatment was observed at 60 and 100 days after the beginning of supplementation (DOMINGUEZ et al., 2017), whereas when evaluating the effects of supplementation of a hydroxy methionine analogue on weight gain, body condition score and milk yield in beef cows CLEMENTS et al. (2017) presented no differences between supplemented animals and the control group. Similar results were observed by WATERMAN et al. (2012) when investigating the effects of protected methionine on plasma amino acid concentrations in beef heifers at the end of pregnancy; no differences in weight gain and body condition score were observed in the supplemented group, nor were birth weights similar of calves between treatments.

Several studies evaluated the effects of using protected methionine on the productive performance of dairy cows. A meta-analysis including 35 experiments showed a significant increase in milk protein amounts in cows daily supplemented with $25 \mathrm{~g}$ of methionine daily (VYAS; ERDMAN, 2009). When investigating the productive performance, OSORIO et al. (2013) observed that multiparous dairy cows, supplemented with methionine, produced $3.4 \mathrm{~kg}$ more milk per day, with a higher percentage of protein $(0.18 \%)$ and $0.18 \mathrm{~kg}$ more fat in milk per day, and also with the highest energy corrected milk production, corresponding to $3.9 \mathrm{~kg}$ per day. Recently, the productive performance of 81 Holstein cows supplemented with methionine protected from ruminal degradation was evaluated during the transition period, proving that supplemented cows had higher dairy production in kilograms per day (44.30 vs. 40.30), and higher percentage of milk protein (3.32 vs. 3.14) (ZHOU et al., 2016b). Using another source of methionine protected by ethyl cellulose, the same research group developed a study with 60 multiparous Holstein cows, finding a higher intake of dry matter in supplemented animals throughout the transition period, with a consequent increase in milk yield, fat yield, and milk protein (BATISTEL et al., 2017).
Increasing advances in diet formulations by adding the minimum amino acid requirements, coupled with recent research in the field, led to a significant increase in demand for methionine supplements protected from ruminal degradation by dairy properties. Such fact boosted the industrial sector, and the emergence of new products available in the market led to the elaboration of research to verify the comparative effects between three different sources of methionine protected from ruminal degradation on milk production in dairy cows. In total, 12 multiparous Holstein cows were used in a $4 \times 4$ Latin square and supplemented for a period of 21 days. Treatments included a control diet based on corn silage and alfalfa pasture, and the other groups incremented with one of the three main sources of methionine available on the market. Among results, the treatments had no effect on milk yield, milk fat, or lactose concentrations. However, the protein content in milk was high in only one of the evaluated products (ZANG et al., 2017), highlighting the importance of the methionine source to be used.

In this sense, when the influences of the use of protected methionine in relation to productivity were evaluated, the most evident correlation is the increase in protein in milk. Thus, market strategies that allow producers to increase their total composition of solid can accelerate and make these supplementation tools possible. Additionally, some results point out the potentials regarding the increase in milk production and yield, as well as the percentage of milk fat. However, even less results proved than the direct correlation between the increase in limiting methionine and the direct synthesis of casein by the mammary gland.

From the productive point of view, regarding weight gain, contradictions in recent literature can still be found, with varied results closely related to the type of animal category studied and total diet composition. In beef cattle kept in pasture, another factor that provides direct influences is the quality and profile of amino acids present in these forages.

Therefore, whereas we found significant differences in weight gain in supplemented nulliparous heifers, in experiments conducted by our research group, other groups of researchers differ present results that differ from these results, by eliminating the association between increased methionine in the face of increased feed conversion and weight gain in multiparous cows. These contradictions led us to broaden our lines of research, and field experiments are currently being conducted to elucidate the real possibilities for performance improvement through a range of methodologies, including zootechnical and molecular evaluations.

\section{CONCLUSION}

The present review indicates the potential benefits of strategic methionine supplementation protected from ruminal 
degradation in cattle, and their influence on aspects related to reproductive efficiency, immune response, and productive performance. The increased nutrient supply during the embryonic implantation period, besides an increase in ovarian activity, stands out among the main advantages in response to reproduction. In view of the immune response, the most evident results are related to the benefits of innate immunity, with a marked increase in phagocytic capacity of neutrophils and monocytes, as well as an important antioxidant effect mediated by products originating from methionine. Finally, when evaluating the influences on productivity, the most direct and proven correlation is the increase in milk protein, associated to a potential increase in total production and higher yield.

| | | | | | | | | | | | | | | | | | | | | | | | | | | | | | | | | | | | | | | | | | | | | | | | | | | | | | | | | | | | | | | | | | | | | | | | | | | | | | | | | | | | | | | | | | | | | | | | | | | | | | | | | | | | | | | | | | | | | | | | | | | | | | | | | | | | | | | | | | | | | | | | | | | | | | | | | | | | | | | | | | | | | | | | | | | | | | | | | | | | | | | | | | | | | | | | | | | | | | | | | | | | | | | | | | | | | | | | | | REFERENCES

ABDELMEGEID, M.K.; VAILATI-RIBONI, M.; ALHARTHI, A. Supplemental methionine, choline, or taurine alter in vitro gene network expression of polymorphonuclear leukocytes from neonatal Holstein calves. Journal of Dairy Science, Champaign, v.100, n.4, p.3155-3162, 2017. https://doi.org/10.3168/jds.2016-12025

ACOSTA, D.A.V.; DENICOL, A.C.; TRIBULO, P.; RIVELLI, M.I.; SKENANDORE, C.; ZHOU, Z.; LUCHINI, D.; CORRÊA, M.N.; HANSEN, P.J.; CARDOSO, F.C. Effects of rumen-protected methionine and choline supplementation on the preimplantation embryo in Holstein cows. Theriogenology, Stoneham, v.85, n.9, p.1669-1679, 2016. https://doi.org/10.1016/j.theriogenology.2016.01.024

ACOSTA, D.A.V.; RIVELLI, M.I.; SKENANDORE, C.; ZHOU, Z.; KEISLER, D.H.; LUCHINI, D.; CORREAA, M.N.; CARDOSO, F.C. Effects of rumen-protected methionine and choline supplementation on steroidogenic potential of the first postpartum dominant follicle and expression of immune mediators in Holstein cows. Theriogenology, Stoneham, v.96, n.1, p.01-09, 2017. https:// doi.org/10.1016/j.theriogenology.2017.03.022

ALONSO, L; MAQUIVAR, M.; GALINA, C.S.; MENDOZA, G.D.; GUZMÁN, A.; ESTRADA, S.; VILLAREAL, M.; MOLINA, R. Effect of ruminally protected Methionine on the productive and reproductive performance of grazing Bos indicus heifers raised in the humid tropics of Costa Rica. Tropical Animal Health and Production, Edinburgh, v.40, n.8, p.667-672, 2008. https://doi.org/10.1007/s1 1250-008-9146-1

ANTONIAZZI, A.Q.; HENKES, L.E.; OLIVEIRA, J.F.C.; HANSEN, T.R. Função do interferon-tau durante o reconhecimento materno da gestação em ruminantes. Ciência Rural, Santa Maria, v.41, n.1, p.176-185, 2011 . http://dx.doi.org/10.1590/ S0103-84782011000100029

BATISTEL, F.; ARROYO, J.M.; BELLINGERI, A.; WANG, L.; SAREMI, B.; PARYS, C.; TREVISI, E.; CARDOSO, F.C.; LOOR, J.J. Ethyl-cellulose rumen-protected methionine enhances performance during the periparturient period and early lactation in Holstein dairy cows. Journal of Dairy Science, Champaign, v. 100, n.9, p.7455-7467, 2017. https://doi.org/10.3168/jds.2017-12689

BATISTEL, F.; ARROYO, J.M.; GARCES, C.I.M.; TREVISI, E.; PARYS, C.; BALLOU, M.A.; CARDOSO, F.C.; LOOR, J.J. Ethyl-cellulose rumen-protected methionine alleviates inflammation and oxidative stress and improves neutrophil function during the periparturient period and early lactation in Holstein dairy cows. Journal of Dairy Science, Champaign, v.101, n. 1, p.480-490, 2018. https://doi. org/10.3168/jds.2017-13185
BETTERIDGE, K.J.; EAGLESOME, M.D.; RANDALL, G.C.; MITCHELL, D. Collection, description and transfer of embryos from cattle 10-16 days after oestrus. Journal of Reproduction and Fertility, Cambridge, v.59, n. 1, p.205-216, 1980. https://doi.org/10.1530/jrf.0.0590205

CALDER, P.C.; YAQOOB, P. Metabolic \& therapeutic aspects of amino acids in clinical nutrition. Boca Raton: CRC Press, 2003. 776p.

CHEN, Z.H.; BRODERICK, G.A.; LUCHINI, N.D.; SLOAN, B.K.; DEVILLARD, E. Effect of feeding different sources of rumenprotected methionine on milk production and $\mathrm{N}$-utilization in lactating dairy cows. Journal of Dairy Science, Champaign, v.94, n.4, p. 1978-1988, 2011 . https://doi.org/10.3168/jds.2010-3578

CLEMENTS, A.R.; IRELAND, F.A.; FREITAS, T.; TUCKER, H.; SHIKE, D.W. Effects of supplementing methionine hydroxy analog on beef cow performance, milk production, reproduction, and preweaning calf performance. Journal of Animal Science, Champaign, v.95, n. 12 , p.5597-5605, 2017. https://doi.org/10.2527/jas2017.1828

DOMINGUEZ, J.H.; LOPES, M.G.; MACHADO, F.A.; SANTOS, E.; LOPES, F.; FRANCK, J.S.; DEL PINO, F.A.B.; FISCHER, G.; CORRÊA, M.N.; SCHMITT, E. Efeito da suplementação de metionina sobre o ganho de peso e diâmetro folicular em novilhas de corte submetidas a protocolo de inseminação artificial em tempo fixo. In: SIMPOSIO INTERNACIONAL DE REPRODUCCION ANIMAL, 12. Cordoba, Argentina. Proceedings... IRAAC, Cordoba, p. 373, 2017.

GONZÁLEZ, F.H.D.; SILVA, S.C. Introdução à bioquímica clínica veterinária. Porto Alegre: Editora da UFRGS, 2006. 364p.

GRAULET, B.; RICHARD, C.; ROBERT, J.C. Methionine availability in plasma of dairy cows supplemented with methionine hydroxy analog isopropyl ester. Journal of Dairy Science, Champaign, v.88, n.10, p.3640-3649, 2005. https://doi.org/10.3168/ jds.S0022-0302(05)73049-6

GROEBNER, A.E.; RUBIO-ALIAGA, I.; SCHULKE, K.; REICHENBACH, H.D.; DANIEL, H.; WOLF, E.; MEYER, H.H.; ULBRICH, S.E. Increase of essential amino acids in the bovine uterine lumen during preimplantation development. Reproduction, Cambridge, v.141, n.5, p.685-695, 201 1. https://doi.org/10.1530/REP-10-0533

HUGENTOBLER, S.A.; DISKIN, M.G.; LEESE, H.J.; HUMPHERSON, P.G.; WATSON, T.; SREENAN, J.M.; MORRIS, D.G. Amino acids in oviduct and uterine fluid and blood plasma during the estrous cycle in the bovine. Molecular Reproduction and Development, New York, v.74, n.4, p.445-454, 2007. https://doi.org/10.1002/mrd.20607 
IKEDA, S.; SUGIMOTO, M.; KUME, S. Importance of methionine metabolism in morula-to-blastocyst transition in bovine preimplantation embryos. The Journal of Reproduction and Development, Tokyo, v.58, n.1, p.91-97, 2012. https://doi. org/10.1262/jrd.11-096h

JACKSON, A. Aminoacids: essential and non-essential? The Lancet, London, v.321, n.8332, p.1034-1037, 1983. https:// doi.org/10.1016/SO 140-6736(83)92656-9

JACOMETO, C.B.; ZHOU, Z.; LUCHINI, D.; TREVISI, E.; CORRÊA, M.N.; LOOR, J.J. Maternal rumen-protected methionine supplementation and its effect on blood and liver biomarkers of energy metabolism, inflammation, and oxidative stress in neonatal Holstein calves. Journal of Dairy Science, Champaign, v.99, n.8, p.6753-6763, 2016. https://doi.org/10.3168/jds.2016-11018

JAENISCH, R.; BIRD, A. Epigenetic regulation of gene expression: how the genome integrates intrinsic and environmental signals. Nature Genetics, New York, v.33, suppl., p.245-254, 2003. https://doi.org/10.1038/ng1089

LI, P.; YIN, Y.L.; LI, D.; KIM, S.W.; WU, G. Amino acids and immune function. British Journal of Nutrition, Cambridge, v.98, n.2, p.237252, 2007. https://doi.org/10.1017/S000711450769936X

MARTÍNEZ, Y.; LI, X.; LIU, G.; BIN, P.; YAN, W.; MÁS, D.; VALDIVIÉ, M.; HU, C.A.; REN, W.; YIN, Y. The role of methionine on metabolism, oxidative stress and diseases. Amino Acids, Wien, v.49, n. 12, p.2091-2098, 2017. https://doi.org/10.1007/ s00726-017-2494-2

MARTINOV, M.V.; VITVITSKY, V.M.; BANERJEE, R.; ATAULLAKHANOV, F.I. The logic of the hepatic methionine metabolic cycle. Biochimica et Biophysica Acta, Amsterdam, v. 1804, n. 1, p.89-96, 2010. https://doi.org/10.1016/j.bbapap.2009.10.004

NICIURA, S.C.M.; SARAIVA, N.Z. Epigenética: Bases moleculares, efeitos na fisiologia e na patologia, e implicações para a produção animal e vegetal. Brasília: Embrapa, 2014. 286p.

NISWENDER, G.D.; JUENGEL, J.L.; SILVA, P.J.; ROLLYSON, M.K.; MCLNTUSH, E.W. Mechanisms controlling the function and life span of the corpus luteum. Physiological Reviews, Bethesda, v.80, n.1, p.01-29, 2000. https://doi.org/10.1152/ physrev.2000.80.1.1

NATIONAL RESEARCH COUNCIL (NRC). Nutrients Requirements of Dairy Cattle: Seventh Revised Edition. Washington: The National Academies Press, 2001. 408p.

OSORIO, J.S.; JI, P.; DRACKLEY, J.K.; LUCHINI, D.; LOOR, J.J. Supplemental Smartamine M or MetaSmart during the transition period benefits postpartal cow performance and blood neutrophil function. Journal of Dairy Science, Champaign, v.96, n. 10, p.62486263, 2013. https://doi.org/10.3168/jds.2012-5790

OSORIO, J.S.; TREVISI, E.; JI, P.; DRACKLEY, J.K.; LUCHINI, D.; BERTONI, G.; LOOR, J.J. Biomarkers of inflammation, metabolism, and oxidative stress in blood, liver, and milk reveal a better immunometabolic status in peripartal cows supplemented with Smartamine M or MetaSmart. Journal of Dairy Science, Champaign, v.97, n.12, p.7437-7450, 2014. https://doi.org/10.3168/ jds.2013-7679
PAUL, S.S.; DEY, A. Nutrition in health and immune function of ruminants. Indian Journal of Animal Sciences, New Delhi, v.2, n.85, p. 103-112, 2015.

PEÑAGARICANO, F.; SOUZA, A.H.; CARVALHO, P.D.; DRIVER, A.M.; GAMBRA, R.; KROPP, J.; HACKBART, K.S.; LUCHINI, D.; SHAVER, R.D.; WILTBANK, M.C.; KHATIB, H. Effect of maternal methionine supplementation on the transcriptome of bovine preimplantation embryos. PLoS One, San Francisco, v.8, n.8, p.e72302, 2013. https://doi.org/10.1371/journal.pone.0072302

REIS, W.L.S.; DETMANN, E.; BATISTA, E.D.; RUFINO, L.M.A.; GOMES, D.I.; BENTO, C.B.P.; MANTOVANI, H.C.; VALADARESFILHO, S.C. Effects of ruminal and post-ruminal protein supplementation in cattle fed tropical forages on insoluble fiber degradation, activity of fibrolytic enzymes, and the ruminal microbial community profile. Animal Feed Science and Technology, Amsterdam, v.218, p.01-16, 2016. https://doi.org/10.1016/j.anifeedsci.2016.05.001

RIBEIRO, E.S.; GRECO, L.F.; BISINOTTO, R.S.; LIMA, F.S.; THATCHER, W.W.; SANTOS, J.E. Biology of preimplantation conceptus at the onset of elongation in dairy cows. Biology of Reproduction, New York, v.94, n.4, p.01-18, 2016. https://doi.org/10.1095/ biolreprod. 115.134908

ROBERTS, R.M.; CHEN, Y.; EZASHI, T.; WALKER, A.M. Interferons and the maternal-conceptus dialog in mammals. Seminars in Cell (2) Developmental Biology, London, v. 19, n.2, p.170-177, 2008. https://doi.org/10.1016/j.semcdb.2007.10.007

SCHWAB, C.G. Balancing diets for amino acids: nutritional, environmental and financial implication. In: TRI-STATE DAIRY NUTRITION CONFERENCE, 19., Fort Wayne, Indiana. Proceedings... The Ohio State University, Columbus, p.01-13, 2010.

SKENANDORE, C.S.; ACOSTA, D.A.V.; ZHOU, Z.; RIVELLI, M.I.; CORRÊA, M.N.; LUCHINI, D.; CARDOSO, F.C. Effects of rumenprotected methionine and choline supplementation on vaginal discharge and uterine cytology of Holstein cows. International Journal of Veterinary Science and Medicine, Cairo, v.5, n. 1, p.0107, 2017. https://doi.org/10.1016/j.jjvsm.2017.05.001

SOUZA, A.H.; CARVALHO, P.D.; DRESCH, A.R.; VIEIRA, L.M.; HACKBART, K.S.; LUCHINI, D.; BERTICS, S.; BETZOLD, N.; WILTBANK, M.C.; SHAVER, R.D. Effect of methionine supplementation during postpartum period in dairy cows II: embryo quality. Journal of Dairy Science, Champaign, v.95, E-Suppl.2, 2012.

SPENCER, T.E.; BAZER, F.W. Developmental biology and role of endometrial glands in uterine function. Havemeyer Foundation Monograph Series, Newmarket, v. 10, n. 1, p.17-19, 2003.

SPENCER, T.E.; JOHNSON, G.A.; BURGHARDT, R.C.; BAZER, F.W. Progesterone and placental hormone actions on the uterus: insights from domestic animals. Biology of Reproduction, New York, v.71, n.1, p.02-10, 2004. https://doi.org/10.1095/ biolreprod. 103.024133

STEELE, W.; ALLEGRUCCI, C.; SINGH, R.; LUCAS, E.; PRIDDLE, H.; DENNING, C.; SINCLAIR, K.; YOUNG, L. Human embryonic stem cell methyl cycle enzyme expression: modelling epigenetic programming in assisted reproduction? Reproductive Biomedicine Online, Cambridge, v.10, n.6, p.755-766, 2005. https://doi. org/10.1016/S1472-6483(10)61120-0 
STOVER, P.J.; DURGA, J.; FIELD, M.S. Folate nutrition and bloodbrain barrier dysfunction. Current Opinion in Biotechnology, London, v.44, n. 1, p.146-152, 2017. https://doi.org/10.1016/j. copbio.2017.01.006

STURMEY, R.G.; REIS, A.; LEESE, H.J.; McEVOY, T.G. Role of fatty acids in energy provision during oocyte maturation and early embryo development. Reproduction in Domestic Animals, Berlin, v.44, suppl.3, p.50-58, 2009. https://doi. org/10.1111/j.1439-0531.2009.01402.x

TIZARD, I.R. Imunologia Veterinária. Rio de Janeiro: Elsevier, 2014. 568p.

VAILATI-RIBONI, M.; ZHOU, Z.; JACOMETO, C.B.; MINUTI, A.; TREVISI, E.; LUCHINI, D.N.; LOOR, J.J. Supplementation with rumen-protected methionine or choline during the transition period influences whole-blood immune response in periparturient dairy cows. Journal of Dairy Science, Champaign, v.100, n.5, p.39583968, 2017. https://doi.org/10.3168/jds.2016-11812

VYAS, D.; ERDMAN, R.A. Meta-analysis of milk protein yield responses to lysine and methionine supplementation. Journal of Dairy Science, Champaign, v.92, n. 10, p.501 1-5018, 2009. https://doi.org/10.3168/jds.2008-1769

WATERMAN, R.C.; CATON, J.S.; LÖEST, C.A.; PETERSEN, M.K.; ROBERTS, A.J. Beef Species Symposium: an assessment of the 1996 Beef NRC: metabolizable protein supply and demand and effectiveness of model performance prediction of beef females within extensive grazing systems. Journal of Animal Science, Champaign, v.92, n.7, p.2785-2799, 2014. https:// doi.org/10.2527/jas.2013-7062
WATERMAN, R.C.; UJAZDOWSKI, V.L.; PETERSEN, M.K. Effects of rumen-protected methionine on plasma amino acid concentrations during a period of weight loss for late gestating beef heifers. Amino Acids, Wien, v.43, n.5, p.2165-2177, 2012. https://doi. org/10.1007/s00726-012-1301-3

WRENZYCKI, C.; HERRMANN, D.; LUCAS-HAHN, A.; GEBERT, C.; KORSAWE, K.; LEMME, E.; CARNWATH, J.W.; NIEMANN, H. Epigenetic reprogramming throughout preimplantation development and consequences for assisted reproductive technologies. Birth Defects Research Part C: Embryo Today, Hoboken, v.75, n. 1, p.0109, 2005. https://doi.org/10.1002/bdrc.20035

ZANG, Y.; SAMII, S.S.; PHIPPS, Z.C.; TAGER, L.R.; MCFADDEN, J.W.; KRAUSE, K.M. Comparative effects of multiple sources of rumen-protected methionine on milk production and serum amino acid levels in mid-lactation dairy cows. The Professional Animal Scientist, Michigan, v.33, n.6, p.692-699, 2017. https://doi. org/10.15232/pas.2017-01641

ZHOU, Z.; BULGARI, O.; VAILATI-RIBONI, M.; TREVISI, E.; BALLOU, M.A.; CARDOSO, F.C.; LUCHINI, D.; LOOR, J.J. Rumen-protected methionine compared with rumen-protected choline improves immunometabolic status in dairy cows during the peripartal period. Journal of Dairy Science, Champaign, v.99, n. 1 1, p.8956-8969, 2016a. https://doi.org/10.3168/jds.2016-10986

ZHOU, Z.; VAILATI-RIBONI, M.; TREVISI, E.; DRACKLEY, J.K.; LUCHINI, D.; LOOR, J.J. Better postpartal performance in dairy cows supplemented with rumen-protected methionine compared with choline during the peripartal period. Journal of Dairy Science, Champaign, v.99, n.11, p.8716-8732, 2016b. https://doi. org/10.3168/jds.2015-10525 